University of Nebraska - Lincoln

DigitalCommons@University of Nebraska - Lincoln

$1-1-2005$

\title{
The Library and the Computer Center: Organizational Patt erns at Land Grant Universities
}

Mary K. Bolin

University of Nebraska--Lincoln, mbolin2@unl.edu

Follow this and additional works at: https://digitalcommons.unl.edu/libraryscience

Part of the Library and Information Science Commons

Bolin, Mary K., "The Library and the Computer Center: Organizational Patt erns at Land Grant Universities" (2005). Faculty Publications, UNL Libraries. 42.

https://digitalcommons.unl.edu/libraryscience/42

This Article is brought to you for free and open access by the Libraries at University of Nebraska-Lincoln at DigitalCommons@University of Nebraska - Lincoln. It has been accepted for inclusion in Faculty Publications, UNL Libraries by an authorized administrator of DigitalCommons@University of Nebraska - Lincoln. 


\title{
The Library and the Computer Center: Organizational Patterns at Land Grant Universities
}

\author{
by Mary K. Bolin
}

\begin{abstract}
The relationship of the academic library with the campus computing center has been an issue since at least the late 1970s. The issue was discussed at length in the 1980s with little effect on existing organizations. Interest in the issue was rekindled in the 1990s, when a number of institutions merged or aligned the library and the computer center, with varying results. The literature assumes or asserts that it is the norm for academic libraries and computing centers to be merged or administratively aligned. A census of land grant universities contradicts such a view. For this homogeneous group of large state universities, the traditional organization, in which the library dean reports to the provost and the computer center is a separate organization, still prevails overwhelmingly.
\end{abstract}

\section{INTRODUCTION}

The words "digital," "virtual," and "electronic" are found on virtually every library Web site, in the titles of many librarians, and in the list of programs and services offered by libraries. Library science has attempted, with some success, to identify itself with information science. Many universities have administrators called "Chief Information Officer (CIO)" and "Vice Provost for Information Technology," and the library may report to that administrator. The literature has many stories of "integration," "convergence," and "synergy" between the library and the computer center. Academic librarians and university administrators may have come to agree with Hirshon's ${ }^{1}$ assertion that the $\mathrm{CIO}$ is "ubiquitous." ${ }^{2}$ But "ubiquitous" is not synonymous with "universal." What is the reality in academic libraries today?

Since the late 1970s, there has been debate and discussion on the roles and relationship of university libraries with university computing centers. The debate was initially driven by the increasing availability of information in electronic formats and by the rapid advances in information technology. It was also driven by the emerging concept of an electronic or digital library. At the same time, professional education for librarians and the field of library science were seeking to emphasize librarians' expertise with information technology. Many library schools became schools of "library and information science."

During the 1980s, the discussion took place primarily among academic librarians, with no ideal path identified. In the 1990s, the issue of the library-computer center relationship was revived by university administrators. During the 1980s and 1990s, a number of institutions of higher education merged or administratively aligned the library and the computer center, with varying results. Examples include the University of Tulsa, where the library reports to a vice provost for Computing and Information Services (who is a former math professor), Gettysburg College, where the library and computer center were combined under a single (nonlibrarian) administrator, and the University of Southern California (USC), here the library dean is university librarian and chief information officer. Tulsa and USC remains merged organizations, while Gettysburg has returned to separate organizations for the library and computer center.

Mary K. Bolin is Professor and Chair, Technical Services Department, University of Nebraska-Lincoln Libraries, 319 Love Library, PO Box 884100, 13th \& R Streets, Lincoln, NE 68588-4100, United States. Email: mbolin2@unl.edu 
Among land grants, the University of Kentucky, Utah State University, and Oregon State University both aligned the library and computing center under a nonlibrarian administrator. All three institutions have since returned to a traditional arrangement with separate administration for the library and the computer center. At the University of Nevada-Reno, the dean of libraries is also the vice president for Information Technology. At the University of Nebraska-Lincoln, the associate vice chancellor for Information Services, who heads the computer center, is a librarian and former dean of libraries, while the libraries are headed by a dean (a librarian) who reports to the vice chancellor for Academic Affairs.

The issue of the relationship between the library and the computer center is a fundamental one for librarians, with implications for librarianship as a profession. Much of the literature focuses on small colleges, and many articles make no distinction between sizes and types of colleges and universities. Much research remains to be done, and many questions remain to be explored. A very basic question is, do academic libraries and computer centers in fact have an administrative relationship at many or most universities, and if so what is that relationship? Is there a typology or taxonomy of such patterns that can be identified? Moreover, what benefits have actually been derived from these reorganizations?

There is a lack of clear data about what organizational changes have actually taken place. The discourse on the issue is confused. When one speaks of an "academic library," it could be the library of a large research university or that of a small college with a few hundred students. While libraries of all types have much in common, it is necessary to examine a more homogeneous population to begin to make sense of the issue of library-computer center relationships.

Land grant universities are an identifiable population of well-known institutions. This study is a descriptive census of the library and computer center relationships at land grant universities. It is a group of universities with similar missions and characteristics. There is at least one in every U.S. state, all but one (Cornell University) are public institutions, and all have a range of undergraduate and graduate programs in the humanities, social sciences, and sciences. They vary in size, but all of them are large enough to have complex organizations with similar problems and challenges.

The purpose of this study is to create a database of information that will add to the literature and which can be used for further study. The data should reveal a taxonomy of new and traditional organizational patterns and reveal how prevalent each pattern is. The resulting study will provide data to help to either support or counteract the view that libraries and computer centers are, or should be, organizationally aligned. The land grant population can be compared with other academic library populations, such as the Association of Research Libraries. The data can be used to help determine not only which organizational patterns are common, but which patterns are successful. More can potentially be inferred from the characteristics of such a homogeneous popula- tion than from data about libraries at institutions of all types and sizes.

The study is descriptive and exploratory. It does not attempt to find correlations or causes, nor does it assert that one organizational model is better than another. The database can serve as the basis of further study, including questions such as the correlation between different organizational models and whether librarians at the university have faculty status, or between size of the institution and the organizational model. Other instruments can be used to supplement the data and explore questions such as the attitudes of librarians, university administrators, and computer center staff toward the organizational arrangement.

\section{LITERATURE REVIEW}

The relationship of the academic library with the campus computer center has been explored in the literature of librarianship for the last 20 years. Some of it is about "transformation," "reengineering," and so on and describes potential relationships between the library and the computer center. Organization is a theme in some of the works that discuss the future of academic libraries and of information resources and technology in higher education. Such literature may look at the organization, or it may discuss the digital or electronic library without regard to the organization that supports it.

Some literature is research based, including surveys, interviews, content analyses, case studies, historical studies, and literature reviews. Much of it, however, while it is based on the substantial knowledge and experience of its authors, is not based on systematic empirical evidence, nor on any qualitative method. There is plenty of advice for administrators, many planning guides and visions of a possible future, and so on. Many articles are the pragmatic response of librarians to pressure from the university administration to find "synergy" with the computer center or to a reorganization imposed from above.

While it has a practical purpose, the literature is grounded in the values of librarianship, statements of vision, and views of the future that are based on a theory of librarianship that includes the need to educate library users to be self-sufficient; the complementary ideal of providing individual help to users; the goal of providing ready access to information resources regardless of format; the use of standards agreed upon by the international library community; cooperation with other libraries; and so on.

Such a theory of librarianship is embedded in a human resources approach that sees library-computer center relations in an organizational context. Much of the literature addresses organizational and human resources development issues such as communication, planning, hiring, credentials and qualifications, morale, and so on.

\section{MAJOR THEMES IN THE LITERATURE}

The idea that the academic library and the campus computing center should collaborate or cooperate in some way was first seen in the library literature at the end of the 1970s. Matthews, ${ }^{3}$ Battin, ${ }^{4}$ and Neff ${ }^{5}$ are frequently cited. The best known of these is Battin. She presented a 
vision of the 1990s, with an electronic library that included a scholarly information center. She described bringing together information resources and explored the role of librarians in delivering them. Matthews' article is usually mentioned as the earliest example of the literature on the issue. He edited a subsequent group of articles ${ }^{6}$ that mulled over the potential relationship, especially in light of libraries' growing use of information technology. Neff is one of the first cautionary administrative blueprints, with a list of reasons why the library should or should not merge with the computer center. These articles are typical of the library-computer center literature of the 1980s. Libraries were making advances in automation and mainframe computing was giving way to universal microcomputing, with more and more applications in higher education and elsewhere.

The "merger debate" continued in a similar vein throughout the 1980s and then seemed dead by 1989. Seiden and Kathman" see "two catalysts" that drove the debate from 1984 to 1987 and from 1992 to the present. The catalyst during the 1980s was the vision of librarians, while during the 1990s it was administrative pressure. The vision of librarians continued to be expressed in the early 1990s by authors such as Martin, ${ }^{8}$ Creth, ${ }^{9}$ and Young, ${ }^{10}$ who saw opportunities in the technological advances that were occurring. The administrative pressure that came to bear in the 1990s had two main sources. One was the rise of academic computing. The campus computer center, as it emerged in the 1960s, had been responsible for administrative uses such as payroll and for some research applications, mainly in the sciences. With the spread of PC computing and the development of the Internet, demand for information technology became universal. University administrators sometimes looked to libraries for leadership of both academic and technological matters.

Another source of the pressure for libraries and computer centers to merge was an inaccurate view of the coming electronic library. Some administrators were convinced that libraries would no longer be needed as physical locations, or even as organizations. They believed that all information was now readily available, for free and needing no intervention or maintenance, on the Internet. White ${ }^{11}$ writes with characteristic candor about the "dangerous myths" of the digital library. He speaks frankly about being realistic about the scholarly needs and output of typical teaching faculty and about the need for librarians to show administrators that the library needs people in addition to computers and databases.

A number of authors discuss the different cultures of the library and the computer center. Garten and Williams ${ }^{12}$ look at the cultural difference from a historical point of view. They describe the emergence of librarianship as a profession in the United States after the Civil War, where it grew along with the modern model of the university. The computer center and computer science have a shorter history. Garten and Williams, like a number of other authors, describe the common professional formation of librarians and their commonly held values and shared standards. Other issues are the faculty status held by many academic librarians, and their tradition of networks and consortia. These things contrast with the various backgrounds of computer center staff, the more ad hoc approach that contrasts with librarians' tradition and conservatism. The higher pay and predominance of men in the computer center versus the library's lower paid and generally female employees are also important to the discussion. Garten and Williams assert that librarians have an understanding of academe and a different role in it than computer center staff, and that any merger will not be a marriage, but perhaps a kind of cohabitation (more like roommates than lovers).

Seiden and Kathman ${ }^{13}$ use "merger and acquisition theory" to assess industry (higher education), enterprise (the library and computer center), and institutional (the college or university) level factors for merging the library and computer center. Industry-level factors include the desire to enhance teaching and the accountability movement of the 1990s, which identified the need to teach students information literacy. Enterprise-level factors included the library's need for the services of the computer center and the supposed overlap of library reference desk and computer center help desk services. Institutional factors included the need to save money and make good use of personnel, campus-wide wiring and technology plans, and administrative devotion to "reengineering" and similar processes.

Mech $^{14}$ takes a historical look at the development of the academic Chief Information Officer (CIO). The CIO is variously defined as one with responsibility for both the library and computing or for both administrative and academic computing. Mech looks at human resources and organizational development issues in the context of the history of higher education. He sees the $\mathrm{CIO}$ as an organic development in that history, analogous to specialization in other areas. He attributes the influence of the business model on higher education as well. Mech finds that there are several patterns of $\mathrm{CIO}$ responsibility, but that the merged library and computer center, or the library and computer center both reporting to a nonlibrarian, is mostly limited to "smaller comprehensive and liberal arts"15 institutions.

While the issue is far from settled, much of the literature of the 1990s accepts the close organizational relationship of the library and the computer center as a fait accompli. A number of articles describe organizational variations and are case studies or planning guides for reorganizing. Dougherty and $\mathrm{McClure}^{16}$ take an organizational development position, giving advice to the provost. They assert that "librarians and computer professionals now realize they are interdependent," 17 which neatly expresses an unproven orthodoxy on the issue.

Hirshon's ${ }^{18}$ much-cited study looked at institutions whose library and computer center have some sort of organizational relationship. He studied a population of 90 institutions identified as having a CIO, which he defines as "an individual to whom both computing and library operations report." ${ }^{19}$ Seventy-four of those institutions were available to participate, and the final study had an $n$ of 47 . Hirshon's study is primarily a guide for implementing one of the models he identifies. He claims that the CIO model is "ubiquitous" and is found in orga- 
nizations of all types and sizes, although smaller 4-year and liberal arts institutions are prominent in his findings. Hirshon summarizes findings for institutions in Carnegie Research, Doctoral, Masters, and Baccalaureate institutions and finds that $22 \%$ of Research institutions, $12 \%$ of Doctoral, $47 \%$ of Masters, and $19 \%$ of Baccalaureate institutions had a CIO as of 1998. ${ }^{20}$ Hirshon's definition of $\mathrm{CIO}$ is a narrow one. The title of $\mathrm{CIO}$ is becoming increasingly common, but its most frequent meaning seems to be "computer center administrator."

Meachen ${ }^{21}$ looks at the campuses of the University of Wisconsin, where all but the two largest, Madison and Milwaukee, have some degree of merger between the library and the computer center. Meachen did a telephone survey of the provost, $\mathrm{CIO}$, and library and computer center employees at the 11 campuses that have a CIO. He also did a separate faculty and student satisfaction study. He remarks on the lack of real research on the topic. The restricted and certainly not random population that he studied showed several variations on the CIO model, and found that the dean of the library was likely to be appointed CIO because he or she saw eye-toeye, academically, with the provost. Meachen found that these mergers were top-down decisions, sometimes because the computer center was not working well. Three of the nine campuses that implemented a merger have now gone back to their previous organizational arrangement.

Several studies have looked at job classifications and job advertisements. Woodsworth and Maylone ${ }^{22}$ looked at 63 jobs in the computer center and library at three institutions to "analyze the presence and degree of similarity in job content." 23 They found that a small number were essentially identical, a large number had requirements for knowledge, skills, and abilities that were similar in part, and that a small number had no similarity. They assert that their findings indicate the need for a common language and single job family for the library and computer center. They also admit, however, that "broad generalization to the entire higher education environment would have required a much larger sample and finer analytical measures. ${ }^{24}$ Lynch and Smith ${ }^{25}$ and Cronin and Henderson ${ }^{26}$ each did content analyses of advertisements for academic librarian positions. They looked at vacancies for electronic or digital resources librarians to see what information technology skills were required. Both sets of authors looked at advertisements over a long period of time, 25 and 10 years, respectively.

Ferguson et al. ${ }^{27}$ make a case for the merged or integrated library and computer center from the perspective of the administrator of such an organization. Ferguson and Metz are librarians, while Spencer is a computer professional. They represent two Carnegie "Baccalaureate-Liberal Arts" institutions (Bucknell University and Wheaton College) and one Carnegie "Master's" institution (Pacific Lutheran University). The authors describe four dimensions of integration-administrative, physical, collaborative, and cultural. Their article asserts that "merging the library and IT operations into a single service organization simply makes sense from both the user's and the administrator's perspective." ${ }^{28}$
The literature shows a need for research of all kinds on all aspects of the topic of library and computer center organization. There is no lack of case studies that show the good, the bad, and the ugly, nor does one need to look far to find ruminations on the historical roots and present-day issues of the library-computer center debate, as well as sage administrative advice for implementing a merger of some sort. There is virtually no research on how widespread these mergers really are, nor in what kinds of institutions they are most often found. Another pressing need is for some sort of evaluation of how well they work, both by assessing outcomes in some way, and by surveying attitudes of all those involved.

\section{METHOD}

The present study is a census of universities whose land grant mission was created by the Morrill Act of 1862. The act provided for universities to teach "agriculture and the mechanic arts." Subsequent acts gave land grant missions to additional institutions. The "1890 land grants" are a group of 17 historically black colleges and universities. In 1994, a group of Native American tribal colleges were given land grant status. The 1890 and 1994 land grants are less homogeneous and, while some are very similar to the original 1862 land grants, many are quite different in size, array of programs offered, and so on. In the interest of homogeneity, the target population for this study is one 1862 land grant in each of the 50 states. The institutions are found at www.higher-ed.org/resources/land_grant_colleges.htm and listed in Appendix A.

The library used for the census is the university's main library. If the institution has a medical library or other major specialized library that may have another reporting relationship, only the main library is included. Some institutions have both an academic and an administrative computing center. Information about both kinds of organizations is included in the census. These organizations have various names such as "Information Technology Services," "Computing Services," and so on. All organizations with general responsibility for academic or administrative computing are included, regardless of terminology. As with the library, if there is a centralized computer center, and in addition there are a number of decentralized computer centers, i.e., if individual colleges or departments have them, these decentralized units are not included.

Terminology varies from institution to institution. In this study, "provost" refers to the vice president for academic affairs, regardless of the title used at a particular university. Likewise, the administrator of an academic library may be the dean, director, or university librarian, among other titles, including vice provost or something similar. "Dean" is used here to refer to all of those titles. Computer center organization and reporting vary widely, as does the terminology for referring to them. The focus here is on the place of the library in the organization, and not on the details of computer center reporting. "Computer center" and "director" are generally used here to refer to the variety of organizational names and administrative titles. 
Information was gathered using the questionnaire in Appendix B. The only data from that questionnaire used here are the reporting relationships of the library and the computer center and whether there is a professional librarian in the administrative chain between the library and the provost.

Data are encoded using the following taxonomy, which describes the relationship between the library and the computer center. It has been asserted that it academic libraries and computer centers are converging, and this taxonomy tests that assertion by measuring the degree of organizational merger.

- Traditional. Library dean reports directly to provost. Computer center director reports separately to provost or to another administrator, such as financial vice president, or there is a vice president for information technology.

- Realign-1. Library dean reports directly to provost and is in charge of both library and computer center.

- Realign-2. Library dean and computer center director each report to a vice provost who is a computer professional and who reports to provost.

- Merge-1. Library and computer center are a single organization with a dean who is a professional librarian who reports to provost.

- Merge-2. Library and computer center are a single organization with a director who is a computer professional who reports to provost.

The taxonomy can be looked at as one of categorical variables, in which institutions fit neatly into one category or another, but it can also be placed on a Likert scale that measures "degree of merger":

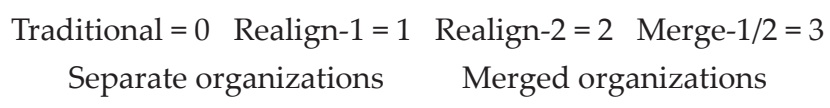

The Web sites of land grant universities were the source of data, using information found there such as organizational charts, factbooks, directories, administrators' individual homepages, and so on. There was ample and definitive information on institutional Web sites that described and depicted organizations and reporting relationships.

\section{RESULTS}

The census had an $n$ of 50 out of the 50 eligible institutions, or $100 \%$ of the population.The results show that $88 \%(n=44)$ of the institutions in the census have the traditional organizational pattern, in which the library reports to the provost and the computer center reports separately to the provost or to some other administrator (Fig. 1). In the $12 \%(n=6)$ that remains, $8 \%(n=4)$ fall into the "realign-1" and "merge- 1 " categories, in which a professional librarian is responsible for both the library and the computer center. In the remaining $4 \%(n=2)$, the "realign-2" category, a nonlibrarian is in charge of the library and computer center (Fig. 2). While one university had a "merge- 1 " model with a librarian in charge of a single library/computer center organization, no institution fell into the "merge-2" category, with a nonlibrarian in charge of a single merged organization.

Such a distribution is similar to Hirshon's (1998) finding for Carnegie classification Research and Doctoral institutions, where $22 \%$ and $12 \%$, respectively, had a CIO, although Hirshon's numbers do not differentiate the models of merger and realignment, and his data are at least 5 years old (Table $\mathbf{1}$ ).

\section{Figure 1 \\ Summary of Data by Category}

\section{Land Grant University Organizational Patterns}

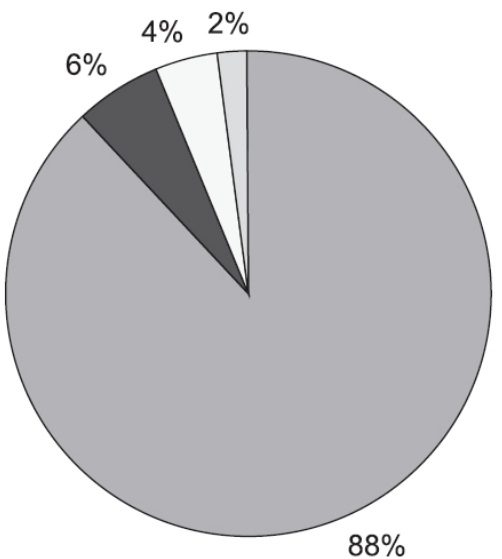

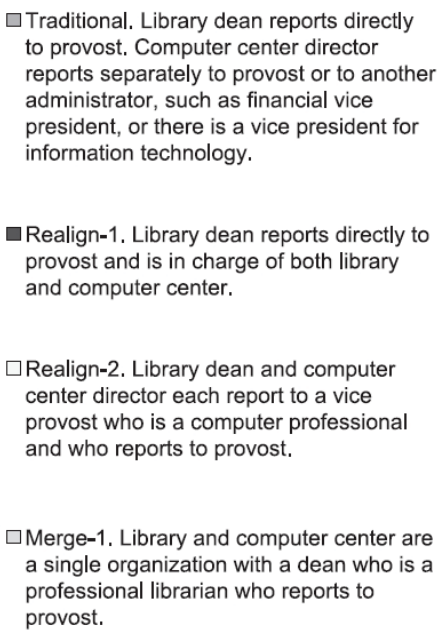


Figure 2

Summary of Categories by Librarian vs. Nonlibrarian Administrator

Land Grant University Library and Computer Center Reporting Relationships

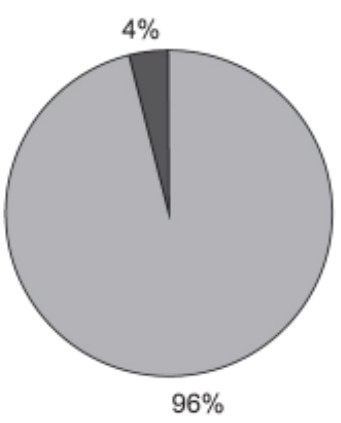

$\square$ Library and compute center report to librarian or to separate administrators

Library and computer center report to nonlibrarian

Table 1

Data Summary

Traditional

Realign-1

Realign-2

Merge-1

Total

Mean degree of merger
44

3

2

1

50

.22

\section{DISCUSSION}

The data are descriptive and exploratory. It is a simple study that attempts to add to the dialogue on a complex, controversial, and emotional issue. It describes organizational patterns in a homogeneous population of libraries but does nothing in itself to explain why those patterns exist. There is potential bias since the issue is examined from the library point of view, and data were gathered with the aim of proving that the merger of the library and the computer center is not universal, and with the underlying opinion that it is not desirable. Further research could help minimize bias, including looking at the literature of computer services and information technology services, including the attitudes of computer center directors and employees in any interviews and surveys, and so on.

In any case, the data provide a source for many intriguing questions and further studies. These include the possibility of both quantitative and qualitative studies. The first question to ask might be, is there a reason why most large universities have retained the traditional pattern? How does the data compare to other groups of academic libraries or universities, e.g., Association of Research Libraries, Carnegie Research-Doctoral institutions, and so on? Further, are there correlations within these groups between size of institution, public vs. private, etc., and organizational pattern? What are the particular characteristics of the institutions that have ad-

opted a merged or realigned organization? What role is played by the administrative flavor or personality of the institution? How does the faculty status of academic librarians affect the organizational pattern? What are the attitudes of librarians, administrators, computer center staff, and students toward these different organizational patterns? Is there an unbiased way to determine the "best" organizational model?

The data show clearly that among land grant institutions, the library and computer center most often remain separate organizations, and that the traditional pattern of organization predominates almost exclusively. These findings confirm Mech's assertion that the merged organization is a phenomenon of smaller institutions, and that when it does occur, the top administrator of the new organization is generally a librarian. These results are in line with Hirshon's findings, in which larger institutions had a lower rate of merger between the library and computer center.

Dougherty's assertion about the interdependency of librarians and computer professionals may reflect the view of college and university administrators that the library and computer center have "synergy"; however, the library has synergy with everyone, and, in a different way, so does the computer center. While organizationally imposed synergy may have worked for some institutions, it may be that the library an computer center can find "synergy," "convergence," and so on, by remaining organizationally distinct, preserving the strengths of each.

\section{NOTES AND REFERENCES}

1. Arnold Hirshon. Integrating Computing and Library Services: an Administrative Planning and Implementation Guide for Information Resources. CAUSE Professional Paper series 18, published in cooperation with the Coalition for Networked Information. Boulder, CO: 1998.

2. Hirshon, "Integrating," p. 1.

3.William D. Matthews. "Creating an Agenda." Journal of Library Automation 12 (Mar. 1979): 361-378.

4. Patrcia Battin. "The Electronic Library: a Vision of the Future," Educom Bulletin 19 (Summer 1984): 12-17.

5. Raymond K. Neff. "Merging Libraries and Computer Centers: Manifest Destiny or Manifestly Deranged? An Academic Services Perspective." Educom Bulletin, 20:4 (Winter 1985): 8-12.

6.William D. Matthews (Ed). "The Library and the Computer Center." Journal of Library Automation, 12 (1979): 361378.

7. Peggy Seiden, Michael D. Kathman. "A History of the Rhetoric and Reality of Library and Computing Relationships." In Books, Bytes, and Bridges: Libraries and Computer Centers in Academic Institutions, edited by Larry Hardesty. (Chicago: American Library Association, 2000) pp. 1-12 (10).

8. Marilyn J. Martin. "Academic Libraries and Computing Centers: Opportunities for Leadership." Library Administration and Management 6 (Spring 1992): 77-81. 
9. Shiela D. Creth. "Creating a Virtual Information Organization: Collaborative Relationships between Libraries and Computing Centers." Journal of Library Administration 19:3-4 (1993): 111-132.

10. Arthur P. Young. "Information Technology and Libraries: a Virtual Convergence." CAUSE/EFFECT 17:3 (Fall 1994): 5-6.

11. Herbert S. White. "Dangerous Misconceptions about Organizational Development of Virtual Libraries." In Restructuring Academic Libraries: Organizational Development in the Wake of Technological Change, edited by Charles A. McClure. (Chicago: Association of College and Research Libraries, 1997) pp. 54-66.

12. Edward D. Garten, Delmus Williams. "Clashing Cultures: Cohabitation of Libraries and Computing Centers in Information Abundance." In Books, Bytes, and Bridges: Libraries and Computer Centers in Academic Institutions, edited by Larry Hardesty. (Chicago: American Library Association, 2000) pp. 61-72.

13. Seiden and Kathman. "A History of the Rhetoric ..." p. 10.

14. Terrence F. Mech. "The Organizational and Historical Context of the Chief Information Officer's Position." In Books, Bytes, and Bridges: Libraries and Computer Centers in Academic Institutions, edited by Larry Hardesty. (Chicago: American Library Association, 2000) pp. 26-37.

15. Mech, "The Organizational and Historical Context," p. 32 .

16. Richard M. Dougherty, Lisa McClure. "Repositioning Campus Information Units for the Era of Digital Libraries." In Restructuring Academic Libraries: Organizational Development in the Wake of Technological Change, edited by Charles A. McClure. (Chicago: Association of College and Research Libraries, 1997) pp. 67-80.
17. Dougherty and McClure. "Repositioning." p. 78.

18. Hirshon. "Integrating."

19. Hirshon. "Integrating." p. 1.

20. Hirshon. "Integrating." p. 5. (The Carnegie Classification of Institutions of Higher Education is found at www.carnegiefoundation.org/Classification/index.htm).

21. Ed Meachen. "Merged and Unmerged Services: Libraries and Computing in the University of Wisconsin System." In Books, Bytes, and Bridges: Libraries and Computer Centers in Academic Institutions, edited by Larry Hardesty. (Chicago: American Library Association, 2000) pp. 83-96.

22. Anne Woodsworth, T. Maylone. Reinvesting in the Information Job Family: Context, Changes, New Jobs, and Models for Evaluation and Compensation. CAUSE Professional Paper series 14, published in cooperation with the Coalition for Networked Information. Boulder, CO: CAUSE, 1993.

23.Woodsworth and Maylone "Reinvesting" p. 2.

24.Woodsworth and Maylone "Reinvesting" p. 8.

25. Beverly P. Lynch, Kimberly Robles Smith, K. "The Changing Nature of Work in Academic Libraries." College and Research Libraries 62:5 (Sept. 2001): 408-420.

26. Karen S. Cronin, Pat Henderson. "Electronic and Digital Library Positions: a Content Analysis of Announcements from 1990 through 2000." Journal of Academic Librarianship 28:4 (July 2002): 232-238.

27. Chris Ferguson, Gene Spencer, Terry Metz. “Greater than the Sum of Its Parts: the Integrated IT/Library Organization." Educause, May/June 2004: 39-46.

28. Ferguson, Spencer, Metz. “Greater,” p. 39. 
Appendix A

Patterns of Organization

\begin{tabular}{|c|c|c|c|}
\hline$\underline{\text { State }}$ & University & Organization & Degree \\
\hline $\mathrm{AK}$ & University of Alaska, Fairbanks & merge-1-librarian admin. & 4 \\
\hline AL & Auburn University & traditional & 0 \\
\hline $\mathrm{AR}$ & University of Arkansas & traditional & 0 \\
\hline $\mathrm{AZ}$ & University of Arizona & traditional & 0 \\
\hline CA & University of California & traditional & 0 \\
\hline $\mathrm{CO}$ & Colorado State University & traditional & 0 \\
\hline CT & University of Connecticut & traditional & 0 \\
\hline $\mathrm{DE}$ & University of Delaware & traditional & 0 \\
\hline FL & University of Florida & traditional & 0 \\
\hline GA & University of Georgia & traditional & 0 \\
\hline $\mathrm{HI}$ & University of Hawaii & traditional & 0 \\
\hline IA & Iowa State University & traditional & 0 \\
\hline ID & University of Idaho & realign-2-computer admin. & 2 \\
\hline IL & University of Illinois & traditional & 0 \\
\hline IN & Purdue University & traditional & 0 \\
\hline KS & Kansas State University & traditional & 0 \\
\hline KY & University of Kentucky & traditional & 0 \\
\hline LA & Louisiana State University & traditional & 0 \\
\hline MA & University of Massachusetts & traditional & 0 \\
\hline MD & University of Maryland, College Park & traditional & 0 \\
\hline $\mathrm{ME}$ & University of Maine* & traditional & 0 \\
\hline MI & Michigan State University & realign-2-computer admin. & 2 \\
\hline $\mathrm{MN}$ & University of Minnesota & traditional & 0 \\
\hline $\mathrm{MO}$ & University of Missouri & traditional & 0 \\
\hline MS & Mississippi State University & traditional & 0 \\
\hline MT & Montana State University-Bozeman & traditional & 0 \\
\hline $\mathrm{NC}$ & North Carolina State University & traditional & 0 \\
\hline ND & North Dakota State University & traditional & 0 \\
\hline NE & University of Nebraska-Lincoln & traditional & 0 \\
\hline $\mathrm{NH}$ & University of New Hampshire & traditional & 0 \\
\hline NJ & Rutgers-The State University of New Jersey & traditional & 0 \\
\hline NM & New Mexico State University & traditional & 0 \\
\hline NV & University of Nevada, Reno & realign-1-librarian admin. & 1 \\
\hline NY & Cornell University & traditional & 0 \\
\hline $\mathrm{OH}$ & Ohio State University & traditional & 0 \\
\hline $\mathrm{OK}$ & Oklahoma State University & traditional & 0 \\
\hline OR & Oregon State University** & traditional & 0 \\
\hline PA & Pennsylvania State University & traditional & 0 \\
\hline RI & University of Rhode Island & realign-1-librarian admin. & 1 \\
\hline SC & Clemson University & traditional & 0 \\
\hline SD & South Dakota State University & traditional & 0 \\
\hline $\mathrm{TN}$ & University of Tennessee & traditional & 0 \\
\hline $\mathrm{TX}$ & Texas A\&M University & traditional & 0 \\
\hline UT & Utah State University ${ }^{* * *}$ & traditional & 0 \\
\hline VA & Virginia Polytechnic Institute and State University & traditional & 0 \\
\hline VT & University of Vermont & realign-1-librarian admin. & 1 \\
\hline WA & Washington State University & traditional & 0 \\
\hline WI & University of Wisconsin-Madison & traditional & 0 \\
\hline WV & West Virginia University & traditional & 0 \\
\hline WY & University of Wyoming & traditional & 0 \\
\hline
\end{tabular}

*Library dean is dean of Cultural Affairs and Libraries.

** Library dean reports to vice provost for Academic Affairs. 


\section{Appendix B}

\section{Data Gathered from Each Web Site}

1. What is the title of the head of the library?
A. Dean
B. Director
C. University Librarian
D. Vice Provost
E. Other

2. Is the head of the library a professional librarian with a masters degree in library science?
A. Yes
B. No

3. To whom does he or she report?
A. Provost
B. Vice Provost
C. Other

4. Do the professional librarians at this institution have faculty status?
A. Yes
B. No

5. Are the professional librarians on tenure-track?
A. Yes
B. No
C. NA

6. Do the professional librarians have professorial rank?
A. Yes
B. No
C. NA

7. What is the computer center called?

8. What is the title of the head of the computer center(s)

9. To whom does he or she report? 